\title{
The Accuracy of Elisa Versus Latex Agglutination Tests in Diagnosis of Rotavirus Acute Gastroenteritis and the Clinical Usefulness of C- Reactive Protein in Iraqi Children
}

\author{
Ali Ibrahim Ali Al-Ezzy \\ Department of Pathology, College of Veterinary Medicine, Diyala University, Diyala, Iraq
}

\begin{abstract}
Citation: Al-Ezzy AIA. The Accuracy of Elisa Versus Latex Agglutination Tests in Diagnosis of Rotavirus Acute Protein in Iraqi Children. SEE J Immunol 2016 Dec 24; 2016:20008. https://doi.org/10.3889/seejim.2016.20008

Keywords: Rotavirus; ELISA Latex agglutination; accuracy age; gender; CRP.

Correspondence: Ali Ibrahim Ali Al-Ezzy. Department of Pathology, College of Veterinary Medicine, Diyala University, Received: 12-Jan-2016; Revised: 10-Mar-2016; Accepted: 13-Mar-2016; Published: 24-Dec-2016

Copyright: ๑ 2016 Ali Ibrahim Ali Al-Ezzy. This is an openaccess article distributed under the terms of the Creative Commons Attribution-NonCommercial 4.0 International Licens

Funding: This research did not receive any financial support. Competing Interests: The author has declared that no competing interests exist.
\end{abstract}

\begin{abstract}
AIM: The aim is to evaluate the accuracy of ELISA versus Latex agglutination tests in the diagnosis of rotavirus. Evaluate the usefulness of C-reactive protein (CRP) level in rotavirus diagnosis and the possible effect of age and gender in CRP level.

METHODS: Detection of viral antigen in faecal samples via ELISA and Latex agglutination tests. CRP detected in (80) children serum samples.

RESULTS: The range of CRP level was (6-96 mg/dl). ELISA more Sensitive (84.62\%) than latex agglutination $(61.11 \%)$ in the diagnosis of rotavirus, although the specificity of latex agglutination was $90.91 \%$ versus $(74.07 \%)$ in ELISA. Both tests give identical accuracy $(77.5 \%)$ in the detection of rotavirus. Moderate agreement reported between ELISA and latex agglutination in the diagnosis of rotavirus (kappa value $=0.534$ ). A significant difference and inverse correlation between male; female and CRP level were detected. Age significantly correlated with latex agglutination results $(p=0.013)$. CRP level inversely correlated with latex agglutination and ELISA results $(p=0.000)$. ELISA results inversely correlated with latex agglutination $(p=0.000)$.
\end{abstract}

CONCLUSIONS: Although ELISA appears to be more sensitive in rotavirus diagnosis, latex agglutination has the same accuracy and can be used in an emergency (take into consideration the false positive results) as an alternative method for rotavirus diagnosis. Latex agglutination results affected by age which is an important drawback. CRP level inversely correlated with gender, latex agglutination and ELISA results.

\section{Introduction}

Diarrhoea remains the second leading cause of death around the world for children under five years of age [1]. Rotavirus is a member of the genus Rotavirus, family Reoviridae, and it is an important causative agent of acute gastroenteritis in children and many young animal species worldwide [1]. There are five species of this virus, referred to as A, B, C, D, and $E$. Rotavirus $A$, the most common species, causes more than $90 \%$ of infections in humans [2]. By the age five, nearly every child in the world has been infected with rotavirus at least once [3].

It has been estimated that rotavirus infections caused 25 million clinical cases, 2 million hospital admissions and about 611,000 deaths annually worldwide in children, most of them occurred in developing countries [4]. About $82 \%$ of rotavirus deaths occurred among children in the poorest countries [5]. The disease causes many symptoms mainly diarrhoea, nausea, malaise, headache, abdominal cramping, fever and vomiting. However, the infection can be symptomless sometimes [2]. The World Health Organization (WHO) has encouraged the introduction of a rotavirus vaccine into national immunisation programs, particularly in poorer countries [6]. Pre-vaccine surveillance to estimate the burden of rotavirus disease, prevalent rotavirus genotypes and the association between rotavirus disease and intussusceptions helps in monitoring the impact of vaccination [7].

The laboratory diagnosis of rotavirus infections plays an important role in the treatment of the disease and also control of its outbreaks [8]. Human serotypes of rotavirus do not grow readily in 
tissue culture and therefore, are difficult to be isolated from the clinical specimens [8]. The laboratory diagnosis of rotavirus infections relies on direct observation of virus by (EM) and/or detection of viral antigens by Enzyme-Linked Immunosorbent Assay (ELISA) and Radioimmunoassay (RIA). These procedures, however, are technically demanding and require specialised equipment which limit their application.

The aim of the present study is to evaluate the accuracy of ELISA versus Latex agglutination tests in the diagnosis of rotavirus-associated acute gastroenteritis in Iraqi children. Evaluate the usefulness of C-reactive protein (CRP) level in rotavirus diagnosis and to determine the possible effect of age and gender in CRP level among patients.

\section{Material and Methods}

In this cross-sectional, hospital-based study, a total of $(80)$ diarrheic children attended to outpatient's clinic of Baghdad teaching hospital during a period from January to December 2015 enrolled in this study. This a study conducted according to the principles of Helsinki declaration. Dully-filled consent form obtained from all patients parents before participating in the study. Approval of ethical review Committee (Issue No. 1/232-15, January 2015), College of Medicine Diyala University-Iraq was taken before initiation of the work.

\section{Methods}

The stool sample was collected in sterile containers, then separated into two parts, the first part was sent to a laboratory for immediate testing by using Rotagen latex agglutination (bio kit, Spain) [9], the kit contains latex particles coated with antirota Virus Antibodies. A sample considered positive for Rotavirus when agglutination was observed within two minutes reaction, as recommended by the kit manufacturer. Second part stored at $-20^{\circ} \mathrm{C}$ until examination and used for detection of rotavirus antigen particles in stool specimens by using ELISA (Epitope Diagnostics) [10]. The assay is a double sandwich method. The assay carried out according to the manufacturer instructions.

\section{CRP-latex agglutination}

Reagents and samples allowed reaching room temperature. About $50 \mu \mathrm{L}$ of the sample and one drop of each positive and negative control were added to separate circles on the slide test. Then the CRPlatex reagent was mixed vigorously before using and $(50 \mu \mathrm{L})$ was added next to the samples to be tested.
The drops mixed with a stirrer, spreading them over the entire surface of the circle. The slide was placed on a mechanical rotator at 80-100 r.p.m. for 2 minutes. False positive results could appear if the test read later than two minutes. The approximate CRP concentration in the patient sample is calculated as follow [11] : $6 \times$ CRP Titer $=\mathrm{mg} / \mathrm{L}$

\section{Statistical analysis}

Demography and cross tabulation were calculated by Statistical analysis using SPSS for Windows TM version 17.0. Pearson correlation used to estimate categorical data correlations. The level of significance was 0.05 (two-tail) in all statistical testing; significant of correlations also include 0.01 (two-tail). The level of confidence limits was 0.095 .

Sensitivity, specificity, positive, negative predictive values, the positive and negative likelihood ratios, the accuracy, and the corresponding 95\% confidence intervals for all tests were calculated using MedCalc statistical software, Version 13.1.1, Belgium. The concordance of the ELISA and Latex agglutination studied using the Cohen's kappa index of agreement. The level of confidence limits was 0.095 and here is one possible interpretation of Kappa value [12]: (a) Poor agreement = Kappa value Less than 0.20; (b) Fair agreement $=$ Kappa value 0.20 to 0.40 ; (c) Moderate agreement $=$ Kappa value 0.40 to 0.60; (d) Good agreement = Kappa value 0.60 to 0.80; and (e) Very good agreement = Kappa value 0.80 to 1.00 .

\section{Results}

In this study, (80) children with diarrhoea were involved. As shown in Table 1 the minimum age of infected children was (1) months while maximum age was seven years and the mean age was 1.23 years. Males represent $(62.5 \%)$, and the rest $(37.5 \%)$ were females. The minimum CRP level $(6 \mathrm{mg} / \mathrm{dl})$ while the maximum was $(96 \mathrm{mg} / \mathrm{dl})$.

Table 1: General description of patients' age, gender and CRP level

\begin{tabular}{|c|c|c|}
\hline \multirow{3}{*}{ Age } & Minimum & 1 (months) \\
\hline & Maximum & 7 years \\
\hline & Mean \pm SD & $1.23 \pm 1.61$ (years) \\
\hline \multirow{4}{*}{ Gender } & & \\
\hline & Male & $50(62.5 \%)$ \\
\hline & Female & $30(37.5 \%)$ \\
\hline & Total & $80(100 \%)$ \\
\hline \multirow{10}{*}{$\operatorname{CRP}(\mathrm{mg} / \mathrm{dl})$} & Minimum & 6 \\
\hline & Maximum & 96 \\
\hline & Mean \pm SD & $31.725 \pm 30.582$ \\
\hline & CRP value & NO. $(100 \%)$ \\
\hline & 6 & $13(16.3 \%)$ \\
\hline & 12 & $29(36.3 \%)$ \\
\hline & 24 & $12(15 \%)$ \\
\hline & 48 & $14(17.5 \%)$ \\
\hline & 96 & $12(15 \%)$ \\
\hline & Total & $80(100 \%)$ \\
\hline
\end{tabular}


As shown in Table 2, ELISA method more Sensitive $(84.62 \%)$ than latex agglutination $(61.11 \%)$ in the diagnosis of rotavirus, although the specificity of latex agglutination was $90.91 \%$ versus $(74.07 \%)$ in ELISA. Both tests give the same accuracy $(77.5 \%)$ in the detection of rotavirus in stool samples. Moderate agreement between ELISA and latex agglutination in the diagnosis of rotavirus (kappa value $=0.534$ ).

Table 2: Accuracy Evaluation of ELISA versus Latex agglutination in diagnosis of rotavirus

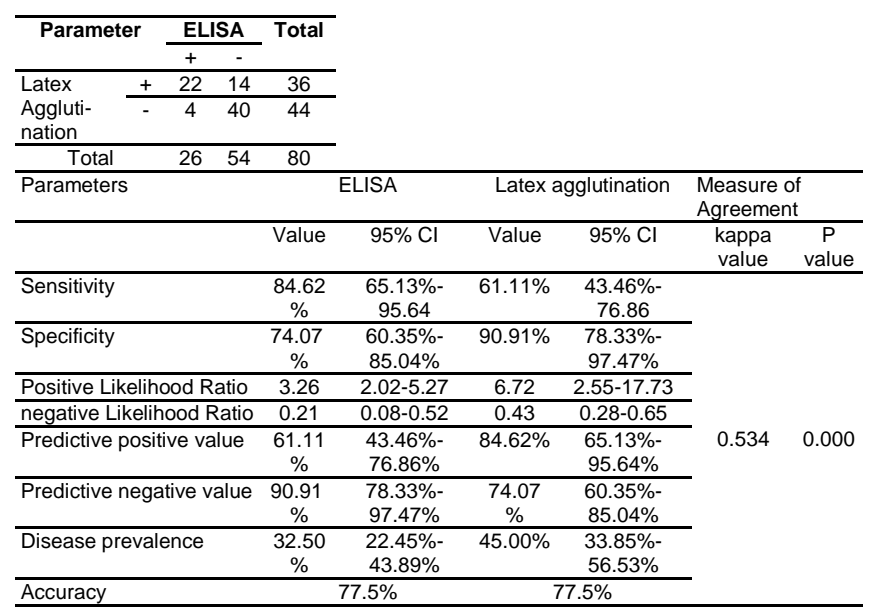

Table 3 have shown that among the age group $(<1)$ year, Rota virus detected by ELISA in (10\%), with CRP level $12 \mathrm{mg} / \mathrm{dl}$ (2.5\%), $24 \mathrm{mg} / \mathrm{dl}, 48$ $\mathrm{mg} / \mathrm{dl}(3.75 \%)$. Rota virus was detected by latex agglutination (28.75\%), with CRP level $12 \mathrm{mg} / \mathrm{dl}$
(8.75\%). Age group was (1-3) year, Rota virus detected by ELISA in $(12.5 \%)$, with CRP level 48 $\mathrm{mg} / \mathrm{dl}(3.75 \%), 96 \mathrm{mg} / \mathrm{dl}(8.75 \%)$. Rota virus detected by latex agglutination (15\%), with high CRP level 96 $\mathrm{mg} / \mathrm{dl}(10 \%)$.

Among the age group (3.1-5) year, Rotavirus detected by ELISA in (2.5\%), with CRP level $48 \mathrm{mg} / \mathrm{dl}$; $96 \mathrm{mg} / \mathrm{dl}(1.25 \%)$. Rotavirus was detected by latex agglutination (1.25\%), with CRP level $96 \mathrm{mg} / \mathrm{dl}$ $(1.25 \%)$. Among the age group (5.1-7) year, Rotavirus detected by ELISA in (2.5\%), with CRP level $48 \mathrm{mg} / \mathrm{dl}$ $(2.5 \%)$. Rotavirus was not detected by latex agglutination.

As shown in Table 4, Rotavirus detected by ELISA in (41.25\%) male and the CRP level range from $(6-96 \mathrm{mg} / \mathrm{dl})$. Rotavirus detected by Latex agglutination detected in male $(32.5 \%)$ and the CRP level range from $(6-48 \mathrm{mg} / \mathrm{dl})$. A significant difference and inverse correlation between male gender and CRP level were detected. Rotavirus detected by ELISA in $(26.25 \%)$ female and the CRP level range from $(6-48 \mathrm{mg} / \mathrm{dl})$. Rotavirus detected by Latex agglutination in (22.5\%) female and the CRP level range from $(6-12 \mathrm{mg} / \mathrm{dl})$. A significant difference and inverse correlation between female gender and CRP level were detected.

As shown in Table 5, age significantly correlated with latex agglutination result $(p=0.013)$. CRP level inversely correlated with latex agglutination and ELISA results $(p=0.000)$. ELISA results inversely correlated with latex agglutination $(p=0.000)$.

Table 3: Rotavirus distribution according to age and CRP level in diarrheic children

\begin{tabular}{|c|c|c|c|c|c|c|c|c|}
\hline \multirow{2}{*}{$\begin{array}{c}\text { Age group } \\
\text { (year) }\end{array}$} & \multirow{2}{*}{\multicolumn{2}{|c|}{ Parameters }} & \multicolumn{5}{|c|}{ CRP level } & \multirow{2}{*}{ Total } \\
\hline & & & $6 \mathrm{mg} / \mathrm{dl}$ & $12 \mathrm{mg} / \mathrm{dl}$ & $24 \mathrm{mg} / \mathrm{dl}$ & $48 \mathrm{mg} / \mathrm{dl}$ & $96 \mathrm{mg} / \mathrm{dl}$ & \\
\hline \multirow{3}{*}{$<1$} & Rota virus & Positive & $0(0 \%)$ & $2(2.5 \%)$ & $3(3.75 \%)$ & $3(3.75 \%)$ & $0(0 \%)$ & $8(10 \%)$ \\
\hline & ELISA & Negative & $8(10 \%)$ & $20(25 \%)$ & $7(8.75 \%)$ & $0(0 \%)$ & $0(0 \%)$ & $35(43.75 \%)$ \\
\hline & Rota virus & Positive & $0(0 \%)$ & $7(8.75 \%)$ & $10(12.5 \%)$ & $3(3.75 \%)$ & $3(3.75 \%)$ & $23(28.75 \%)$ \\
\hline \multirow{4}{*}{$1-3$} & Rota virus & Positive & $0(0 \%)$ & $0(0 \%)$ & $0(0 \%)$ & $3(3.75 \%)$ & $7(8.75 \%)$ & $10(12.5 \%)$ \\
\hline & ELISA & Negative & $4(5 \%)$ & $7(8.75 \%)$ & $2(2.5 \%)$ & $4(5 \%)$ & $1(1.25 \%)$ & $18(22.5 \%)$ \\
\hline & Rota virus & Positive & $0(0 \%)$ & $0(0 \%)$ & $1(1.25 \%)$ & $3(3.75 \%)$ & $8(10 \%)$ & $12(15 \%)$ \\
\hline & LAT & Negative & $4(5 \%)$ & $7(8.75 \%)$ & $1(1.25 \%)$ & $4(5 \%)$ & $0(0 \%)$ & $16(20 \%)$ \\
\hline \multirow{4}{*}{$3.1-5$} & Rota virus & Positive & $0(0 \%)$ & $0(0 \%)$ & $0(0 \%)$ & $1(1.25 \%)$ & $1(1.25 \%)$ & $2(2.5 \%)$ \\
\hline & ELISA & Negative & $1(1.25 \%)$ & $0(0 \%)$ & $0(0 \%)$ & $1(1.25 \%)$ & $0(0 \%)$ & $2(2.5 \%)$ \\
\hline & Rota virus & Positive & $0(0 \%)$ & $0(0 \%)$ & $0(0 \%)$ & $0(0 \%)$ & $1(1.25 \%)$ & $1(1.25 \%)$ \\
\hline & LAT & Negative & $1(1.25 \%)$ & $0(0 \%)$ & $0(0 \%)$ & $2(2.5 \%)$ & $0(0 \%)$ & $3(3.75 \%)$ \\
\hline \multirow{4}{*}{$5.1-7$} & Rota virus & Positive & $0(0 \%)$ & $0(0 \%)$ & $0(0 \%)$ & $2(2.5 \%)$ & $0(0 \%)$ & $2(2.5 \%)$ \\
\hline & ELISA & Negative & $0(0 \%)$ & $0(0 \%)$ & $0(0 \%)$ & $0(0 \%)$ & $0(0 \%)$ & $0(0 \%)$ \\
\hline & Rota virus & Positive & $0(0 \%)$ & $0(0 \%)$ & $0(0 \%)$ & $0(0 \%)$ & $0(0 \%)$ & $0(0 \%)$ \\
\hline & $\begin{array}{l}\text { LAT } \\
\text { LA }\end{array}$ & Negative & $0(0 \%)$ & $0(0 \%)$ & $0(0 \%)$ & $2(2.5 \%)$ & $0(0 \%)$ & $2(2.5 \%)$ \\
\hline
\end{tabular}

Table 4: Distribution of Rotavirus according to gender and CRP level in diarrheic children

\begin{tabular}{|c|c|c|c|c|c|c|c|c|c|c|c|c|}
\hline \multirow{2}{*}{\multicolumn{3}{|c|}{ Sex }} & \multicolumn{5}{|c|}{ CRP (mg/dl) } & \multirow{2}{*}{ Total } & \multirow[b]{2}{*}{$\chi^{2}$} & \multirow{2}{*}{$P$ value } & \multirow{2}{*}{$\mathrm{R}$} & \multirow{2}{*}{$P$ value } \\
\hline & & & 6 & 12 & 24 & 48 & 96 & & & & & \\
\hline \multirow{4}{*}{ Male } & \multirow{2}{*}{$\begin{array}{c}\text { Rota virus } \\
\text { ELISA }\end{array}$} & Negative & $0(0 \%)$ & $1(1.25 \%)$ & $2(2.5 \%)$ & $4(5 \%)$ & $10(12.5 \%)$ & $17(21.25 \%)$ & \multirow{2}{*}{26.532} & \multirow{2}{*}{0.000} & \multirow[t]{2}{*}{-0.724} & \multirow{2}{*}{0.000} \\
\hline & & Positive & 10 (12.5\%) & $13(16.25 \%)$ & $5(6.25 \%)$ & $4(5 \%)$ & $1(1.25 \%)$ & $33(41.25 \%)$ & & & & \\
\hline & \multirow{2}{*}{$\begin{array}{l}\text { Rota virus } \\
\text { LAT }\end{array}$} & Negative & $0(0 \%)$ & $4(5 \%)$ & $6(7.5 \%)$ & $3(3.75 \%)$ & $11(13.75 \%)$ & $24(30 \%)$ & \multirow[t]{2}{*}{27.607} & \multirow{2}{*}{0.000} & \multirow[t]{2}{*}{-.0596} & \multirow{2}{*}{0.000} \\
\hline & & Positive & 10 (12.5\%) & $10(12.5 \%)$ & $1(1.25 \%)$ & $5(6.25 \%)$ & $0(0 \%)$ & $26(32.5 \%)$ & & & & \\
\hline \multirow{4}{*}{ Female } & \multirow{2}{*}{$\begin{array}{c}\text { Rota virus } \\
\text { ELISA }\end{array}$} & Negative & $0(0 \%)$ & $1(1.25 \%)$ & $2(2.5 \%)$ & $5(6.25 \%)$ & $1(1.25 \%)$ & $9(11.25 \%)$ & \multirow[t]{2}{*}{15.873} & \multirow{2}{*}{0.000} & \multirow[t]{2}{*}{-.0681} & \multirow{2}{*}{0.000} \\
\hline & & Positive & $3(3.75 \%)$ & $14(17.5 \%)$ & $3(3.75 \%)$ & $1(1.25 \%)$ & $0(0 \%)$ & $21(26.25 \%)$ & & & & \\
\hline & \multirow{2}{*}{$\begin{array}{c}\text { Rota virus } \\
\text { LAT }\end{array}$} & Negative & $0(0 \%)$ & $3(3.75 \%)$ & $5(6.25 \%)$ & $3(3.75 \%)$ & $1(1.25 \%)$ & $12(15 \%)$ & \multirow[t]{2}{*}{13.750} & \multirow{2}{*}{0.008} & \multirow[t]{2}{*}{-0.396} & \multirow[t]{2}{*}{0.030} \\
\hline & & Positive & $3(3.75 \%)$ & $12(15 \%)$ & $0(0 \%)$ & $3(3.75 \%)$ & $0(0 \%)$ & $18(22.5 \%)$ & & & & \\
\hline
\end{tabular}


Table 5: Correlation of Rota virus diagnosis, age, gender and CRP level in diarrheic children

\begin{tabular}{llcccc}
\hline Parameters & & Sex & CRP & $\begin{array}{c}\text { Latex } \\
\text { Agglutination }\end{array}$ & ELISA \\
\cline { 2 - 5 } Age & $\mathrm{R}$ & 0.014 & 0.185 & 0.277 & -.0174 \\
\cline { 2 - 5 } & $\mathrm{P}$ Value & 0.903 & 0.101 & 0.013 & 0.123 \\
\hline \multirow{2}{*}{ Sex } & $\mathrm{R}$ & -0.212 & 0.078 & 0.041 \\
\cline { 2 - 5 } $\mathrm{P}$ Value & & 0.059 & 0.492 & 0.716 \\
\hline \multirow{2}{*}{$\mathrm{CRP}$} & $\mathrm{R}$ & & -0.534 & -0.688 \\
\hline \multirow{2}{*}{$\begin{array}{l}\text { Latex } \\
\text { Agglutination }\end{array}$} & $\mathrm{r}$ Value & & & 0.000 & 0.000 \\
\cline { 2 - 5 } & $\mathrm{P}$ Value & & & 0.553 \\
\hline
\end{tabular}

\section{Discussion}

Rotavirus is a reason for hospitalisation. It is prevailing in areas where the sanitation and drinking water supply are unhygienic. Children usually are the vulnerable group to many infectious diseases. They are the first victims of any contamination of water and food. In this study, the minimum age of infected children was (1) months while maximum age was seven years and the mean age was 1.23 years. The reported age come in line with that reported in local [13] and international studies in Sudan [2], India [14] and Taiwan [15]. In the current study, males represent $(62.5 \%)$ which come by findings in Iraq $[13,16]$, India [14], and Sudan [2]. The minimum CRP level (6 $\mathrm{mg} / \mathrm{dl})$, the maximum was $(96 \mathrm{mg} / \mathrm{dl})$ and the mean $(31.72 \pm 30.58 \mathrm{mg} / \mathrm{dl})$. The CRP level of $>50 \mathrm{mg} / \mathrm{dl}$ in current study approximates to CRP reported in rotavirus gastroenteritis in Taiwan [15]. In the current study, a high Rotavirus-associated gastroenteritis detected in $32.5 \%$ according to ELISA, $45 \%$ according to Latex agglutination. This result was lower than reported cases in Erbil-Iraq (37\%) [17] probably due to environmental factors in northern Iraq higher than reports from another local study (18.75\%) [18]. In other countries like India in which a total of $21 \%$ of diarrhoea cases of children $<5$ years of age were positive for rotavirus using ELISA in Punjab; Chandigarh (16-19\%), Kolkata (5-22\%) and Chennai $(20.8 \%)$ in India [14]. The current prevalence of rotavirus-associated acute gastroenteritis come within range detected in Middle Eastern and North African countries (16\% to $61 \%$ ) per year [19].

ELISA method more Sensitive (84.62\%) than latex agglutination $(61.11 \%)$ in the diagnosis of rotavirus and this finding agree with [16] found $(77.4 \%)$ sensitivity and [20] found that ELISA (86.52\%) sensitive than Latex agglutination (81\%). Current result disagrees with previous local [13] and international studies[8]. Although in the current study, specificity of latex agglutination was $90.91 \%$ versus $(74.07 \%)$ in ELISA. In contrast [13] reported that specificity of latex agglutination was $86.3 \%$ versus $93.6 \%$ for ELISA. These results concluded that strongly positive reactions found by Latex Agglutination may be regarded as true positive reactions, whereas samples producing weakly positive and negative reactions should be retested in a more specific and sensitive assay, such as enzyme-linked immunosorbent assay (ELISA). In the current study, the percentage of false negative reaction in ELISA was 0.21 compared with $7.7 \%$ in the previous local study [13], while the negative reaction was 0.43 for latex agglutination compared with $3.3 \%$ in [13]. These false negative reactions may be due to the several reasons: the monoclonal antibodies that sensitise the latex particle and may not be detecting the serotype; the viral antigens could be lower than the technique sensitivity; and the faeces may contain unspecific inhibitors or $\lg A$ antibodies, resulting in weak agglutination reaction, not detected by the technician [13].

Other possible reasons for latex positive but ELISA negative results, this may be due to false positive latex tests as ELISA is more sensitive, or that because of the subjectivity of the reader since naked eye reads latex. It is very important when reading latex tests to compare with positive and negative controls. The other reason could be that the testing samples with latex after high-speed centrifugation affects results and may be a possible cause of falsepositive results. Therefore all the new generation latex tests now on the market use a filtration process of the stool samples [16]. In the current study, both tests give the same accuracy $(77.5 \%)$ in the detection of rotavirus in stool samples. A Moderate agreement between ELISA and latex agglutination in the diagnosis of rotavirus (kappa value $=0.534$ ) reported in current study .unfortunately no recent studies determine the degree of agreement between these tests. This moderate agreement may attribute to false positive results in latex agglutination.

In current study, among the age group $(<1)$ year, Rotavirus detected by ELISA in (10\%), with CRP level $12 \mathrm{mg} / \mathrm{dl}$ (2.5\%), $24 \mathrm{mg} / \mathrm{dl}$, and $48 \mathrm{mg} / \mathrm{dl}$ (3.75\%). Rotavirus was detected by latex agglutination (28.75\%), with CRP level $12 \mathrm{mg} / \mathrm{dl}$ $(8.75 \%)$. These results higher than Indian study found a CRP level in positive rotavirus cases under one year $(4.748 \pm 2.15 \mathrm{mg} / \mathrm{l})$ [3]. The relatively low incidence of rotavirus infection at this age, suggest the role of maternal antibodies against rotavirus that offers better protection to infants. In the age group (1-3) year, Rotavirus detected by ELISA in (12.5\%), with CRP level $48 \mathrm{mg} / \mathrm{dl}(3.75 \%), 96 \mathrm{mg} / \mathrm{dl}(8.75 \%)$. Rotavirus detected by latex agglutination (15\%), with high CRP level $96 \mathrm{mg} / \mathrm{dl}(10 \%)$. These finding relatively lower than reports from Saudi Arabia (30\%) [21], Iran [22] and Jordan [23]. Among the age group (3.1-5) year, Rotavirus was detected by ELISA in $(2.5 \%)$, CRP level $48 \mathrm{mg} / \mathrm{dl} ; 96 \mathrm{mg} / \mathrm{dl}(1.25 \%)$. Rotavirus was detected by latex agglutination (1.25\%), with CRP level $96 \mathrm{mg} / \mathrm{dl}$ (1.25\%). These results lower than reports from Sudan reported (6.6\%) among the age group of 5 years [1] and rotavirus antigen A was not detected at this age in India [14]. The frequency of rotavirus infection appears to decrease in older children. Among the age group (5.1-7) year, Rotavirus 
detected by ELISA in (2.5\%), with CRP level $48 \mathrm{mg} / \mathrm{dl}$ $(2.5 \%)$. This may reflect the development of protective immunity from previous exposures. In the current study, the CRP among (41.25\%) males with positive ELISA was (6-96 mg/dl). Among (32.5\%) male with positive Latex agglutination, have the CRP (6-48 $\mathrm{mg} / \mathrm{dl})$. The CRP among (26.25\%) female with positive ELISA was (6-48 mg/dl). Among (22.5\%) female were with positive Latex agglutination. The CRP level (6-12 mg/dl). The Higher rate of positive males comes in line with other studies $[13,18]$.

Even there was a marginal correlation between gender and CRP level among diarrheic children, an inverse correlation between CRP level and rotavirus ELISA and Latex agglutination tests in males and females was detected. This probably is due to the severity of diarrheal episodes that associated with general hypoproteinemia which appear as a decrease in CRP serum concentration along with positive rotavirus infection. In the current study, the positivity of latex agglutination significantly correlated with age $(p=0.013)$. This attributed to the fact that exposure to rotavirus in current study appears to be declined with increased age, for this reason, viral particles will be decreased in faecal samples and finally the results of agglutination test affected by false-negative results. For this reason in current study ELISA results inversely correlated with latex agglutination $(p=0.000)$.

In conclusion, although ELISA appears to be more sensitive in rotavirus diagnosis, latex agglutination has the same accuracy and can be used in an emergency (take into consideration the false positive results) as an alternative method for rotavirus diagnosis. Latex agglutination results affected by age which is an important drawback. CRP level inversely correlated with gender, latex agglutination and ELISA results.

\section{References}

1. Elhag W, Saeed H, El Fadhil EO, Ali A. Prevalence of rotavirus and adenovirus associated with diarrhea among displaced communities in Khartoum, Sudan. BMC infectious diseases. 2013; 13(1):209. https://doi.org/10.1186/1471-2334-13-209 PMid:23657114 PMCid:PMC3655852

2. Elawad M, Masaad T. Epidemiology of Rotavirus Infection in Children Less than Five Years in Omdurman Paediatric Hospital, Khartoum, Sudan. International Journal of Biomedical Research. 2015; 6(3):219-222. https://doi.org/10.7439/ijbr.v6i3.1804

3. Khatib PK, Khan ZH. Biochemical studies in serum of children suffering from rotavirus diarrhoea. Bioscience Discovery. 2012;3:25-29.

4. Sai L, Sun J, Shao L, Chen S, Liu H, Ma L. Epidemiology and clinical features of rotavirus and norovirus infection among children in Ji'nan, China Virol J. 2013;10:302. https://doi.org/10.1186/1743422X-10-302 PMid:24099150 PMCid:PMC3851746

5. Magzoub MA, Bilal NE, Bilal JA, Osman OF. Rotavirus infection among Sudanese children younger than 5 years of age: a cross sectional hospital-based study. Pan African Medical Journal. 2014;16(1).
6. Nunes A, Mello L, Parrode R, Bittar J. Prevalence of rotavirus in feces of children with acute diarrhea: clinical signs and associated symptoms. Revista da AMRIGS. 2010;54(2):147-151.

7. Enweronu-Laryea CC, Sagoe KW, Glover-Addy $\mathrm{H}$, Asmah $\mathrm{RH}$, Mingle JA, Armah GE. Prevalence of severe acute rotavirus gastroenteritis and intussusceptions in Ghanaian children under 5 years of age. The Journal of Infection in Developing Countries. 2011;6(02):148-155.

8. Pirkooh AA, Shahrabadi MS. Development of a latex agglutination method for diagnosis of rotavirus infections. Iranian Journal of Medical Sciences. 2015;32(2):100-104.

9. Biokit: Rotagen: Latex agglutination test on slide for the qualitative determination of Rotavirus antigen in stool. Avaibable from: http://www.biokit.com/productos/reagents/rapidtest/rotagen.aspx.

10. Epitopediagnostics: Fecal Rotavirus Antigen ELISA Kit. Avaibable from: http://www.epitopediagnostics.com/ktr841/.

11. SPINREACT: Qualitative determination of C-Reactive Protein (CRP), CRP-Latex Slide agglutination. Avaibable from: www.spinreact.com

12. Viera AJ, Garrett JM. Understanding interobserver agreement: the kappa statistic. Fam Med. 2005;37(5):360-363. PMid:15883903

13. Abood WN. Performance Of Enzyme Linked Immunosorbent Assay Versus Latex Agglutination Test In The Diagnosis Of Acute Gastroenteritis By Rota Virus. Journal of Al-Nahrain University. 2010; 13:107-111.

14. Dhiman S, Devi B, Singh K, Devi P. Comparison of EnzymeLinked Immunosorbent Assay and Immunochromatography for Rotavirus Detection in Children Below Five Years with Acute Gastroenteritis. 2015.

15. Lee W-T, Lin P-C, Lin L-Cn, Chen H-L, Yang R-C. Salmonella/rotavirus coinfection in hospitalized children. The Kaohsiung journal of medical sciences. 2012;28(11):595-600. https://doi.org/10.1016/i.kims.2012.04.025 PMid:23140767

16. Zaman NA-K, Al-Tae A-RA, Saadoon IH. Rotavirus, Enteropathogenic Escherichia coli (EPEC) and Parasitic Etiology of Pediatric Diarrhea in Kirkuk city. In: Second Scientific Conference Science College - Tikrit University Iraq, 2012: 121-124.

17. Ahmed HM CJ, Nakagomi O, Hart CA, Zaki JM, Al-Rabaty AA, et al. Molecular characterization of rotavirus gastroenteritis strains, Iraqi Kurdistan. Emerg Infect Dis. 2006;12(5):824-826. https://doi.org/10.3201/eid1205.051422 PMid:16704845 PMCid:PMC3374452

18. AL-Ezzy AIA, Abood WN. Immuno-Microbiological Diagnosis of Co-Infections with Rota Virus, Giardia lamblia, Entamoeba histolytica And Salmonella enterica As A Possible Pathological Strategy For Acute Diarrhea Among Iraqi Children. International Journal of Advanced Research. 2013;1:216-224.

19. Khoury H, Ogilvie I, El Khoury AC, Duan Y, Goetghebeur MM. Burden of rotavirus gastroenteritis in the Middle Eastern and North African pediatric population. BMC infectious diseases. 2011;

11(1):9. https://doi.org/10.1186/1471-2334-11-9 PMid:21214934 PMCid:PMC3022719

20. Mustafa NS, Elhag WI. JOURNAL OF PHARMACEUTICAL AND BIOMEDICAL SCIENCES. sciences (J Pharm Biomed Sci). 2013; 33(33):1594-1598.

21. Kheyami AM, Cunliffe NA, Hart CA. Rotavirus infection in Saudi Arabia. Annals of Saudi medicine. 2006; 26(3):184.

PMid:16861867

22. Emamghorashi F, Rajabi S, Shadman A. Frequency of

Rotavirus infection in children with acute gastroenteritis in Jahrom, South of Iran. Iranian Journal of Medical Sciences. 2008;33(2):8487.

23. Khuri-Bulos N, Al Khatib M. Importance of rotavirus as a cause of gastroenteritis in Jordan: a hospital based study. Scandinavian journal of infectious diseases. 2006;38(8):639-644.

https://doi.org/10.1080/00365540600606515 PMid:16857608 